\title{
Simultaneous Determination of Ranitidine Hydrochloride and Ondansetron Hydrochloride in Bulk Drug and Tablet Dosage Form by UV Spectrophotometry
}

\author{
Priya BD 1 , Lakshmi BV1, Bhavya V1, Ramya V1, Aparna D1, \\ Prasanthi $\mathrm{T}^{2}$ and Rao $\mathrm{AL}^{3 *}$ \\ ${ }^{1}$ Student, Department of Pharmaceutical Analysis, V V Institute of Pharmaceutical \\ Sciences, India
}

${ }^{2}$ Associate Professor, Department of Pharmaceutical Analysis, VV Institute of Pharmaceutical Sciences, India

${ }^{3}$ Professor and Principal, Department of Pharmaceutical Analysis, VV Institute of Pharmaceutical Sciences, India

*Corresponding author: A Lakshmana Rao, Professor and Principal, VV Institute of Pharmaceutical Sciences, Gudlavalleru, Andhra Pradesh, India, E-mail: dralrao@gmail.com

\section{Abstract}

A simple, accurate and economic UV Spectrophotometric method was developed for simultaneous estimation of Ranitidine Hydrochloride (RNH) and Ondansetron Hydrochloride (ODH) in bulk drug and tablet dosage form. Distilled water was used as solvent for analysis. The wavelengths selected for determination of Ranitidine was found to be 227.8 $\mathrm{nm}$ and for Ondansetron was found to be $248.7 \mathrm{~nm}$. The linearity was found to be satisfactory in the concentration range of $2-10 \mu \mathrm{g} / \mathrm{ml}$ for both RNH and ODH. Regression analysis reveals that the correlation coefficient was found to be 0.9976 for RNH and 0.9979 for ODH. The \%RSD values for intra-day precision and inter-day precision for Ranitidine were found to be $0.58 \%$ and $0.96 \%$ and for Ondansetron were found to be $0.44 \%$ and $0.54 \%$ respectively. The mean recovery of the drugs RNH and ODH was 99.36\% and 99.51\% respectively. The proposed method was validated as per ICH guidelines and the results are in accordance with acceptance criteria. Hence the present described method can be identically used for analysis of Ranitidine Hydrochloride and Ondansetron Hydrochloride in commercial formulation.

Keywords: Ranitidine Hydrochloride; Ondansetron Hydrochloride; UV Spectrophotometry; Linearity

\section{Introduction}

Ranitidine Hydrochloride (Figure 1 ) is a histamine $\mathrm{H}_{2}$ receptor antagonist indicated for the treatment of peptic ulcers [1,2]. The chemical name for Ranitidine Hydrochloride $\quad \mathrm{N}[2-[[[5-[($ dimethylamino $) m e t h y l]-$ 2furanyl]methyl]thio] ethyl]-N'-methyl-2-nitro-1,1- ethenediamine hydrochloride [3,4]. Ranitidine is a competitive, reversible inhibitor of the action of histamine. Ranitidine blocks the production of acid by acid-producing cells in the stomach. Histamine is a naturally-occurring chemical that stimulates cells in the 


\section{Open Access Journal of Pharmaceutical Research}

stomach to produce acid. $\mathrm{H}_{2}$-blockers inhibit the action of histamine on the cells, thus reducing the production of acid by the stomach. They accomplish this by two mechanisms: histamine released by enterochromaffin-like (ECL) cells in the stomach is blocked from binding on parietal cell $\mathrm{H}_{2}$ receptors which stimulate acid secretion, and other substances that promote acid secretion have a reduced effect on parietal cells when the $\mathrm{H}_{2}$ receptors are blocked.

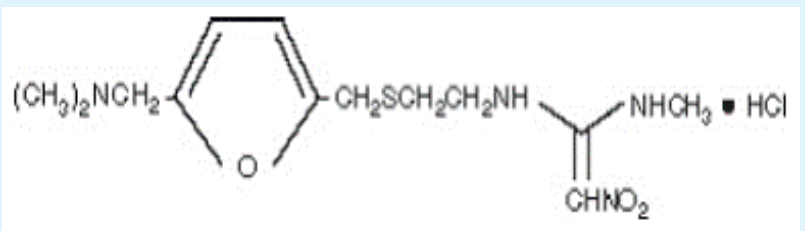

Figure 1: Molecular structure of Ranitidine Hydrochloride.

Ondansetron Hydrochloride (Figure 2) is a selective, competetive serotonin $\left(5-\mathrm{HT}_{3}\right)$ receptor antagonist [5]. The chemical name was $( \pm)$ 1,2,3,9-tetrahydro-9methyl-3-[(2-methyl-1H-imidazol-1-yl)methyl]-4Hcarbazol-4-one, monohydrochloride [6,7]. It is effective in the treatment of nausea and vomiting. The antiemetic activity of the drug is brought about through the inhibition of $5-\mathrm{HT}_{3}$ receptors present both centrally (medullary chemoreceptor zone) and peripherally (GI tract) [8]. This in turn inhibits the visceral afferent stimulation of the vomiting center, likely indirectly at the level of the area postrema through direct inhibition of serotonin activity within the area postrema and the chemoreceptor trigger zone.

On literature survey it was found that few analytical methods were available for simultaneous estimation of Ranitidine Hydrochloride and Ondansetron Hydrochloride by using UV Spectrophotometry and RPHPLC [9-15]. Hence an effort has been made to develop a simple, sensitive, economic and precise UV Spectrophotometric method for simultaneous analysis of $\mathrm{RNH}$ and $\mathrm{ODH}$ and validated as per ICH guidelines.

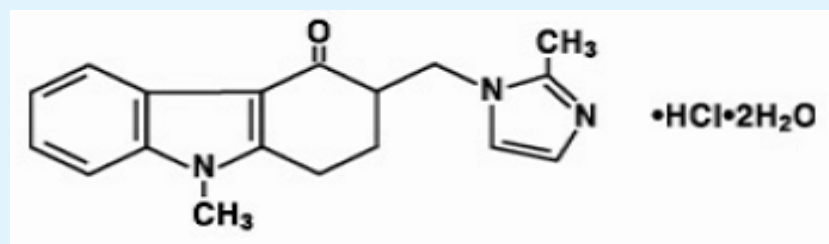

Figure 2: Molecular structure of Ondansetron Hydrochloride.

\section{Method and Materials}

\section{Materials}

Instrument: Shimadzu UV1800 Double Beam Spectrophotometer was used for analysis.

Drugs and formulations: The pure drug samples of Ranitidine Hydrochloride (API) and Ondansetron Hydrochloride (API) were provided as gift samples from Spectrum Labs, Hyderabad, India. The commercial formulations (tablets) (DORAN-O tablets containing 150 mg of Ranitidine Hydrochloride and $4 \mathrm{mg}$ of Ondansetron Hydrochloride) were procured from the local market.

Chemicals and solvents: Distilled water was used as solvent and was used throughout the experiment.

\section{Methodology}

Selection of suitable solvent: Both the drugs RNH and ODH were soluble in distilled water hence the distilled water was used as a solvent for estimation of these drugs.

Preparation of standard stock solution: Accurately weighed $10 \mathrm{mg}$ of Ranitidine and $10 \mathrm{mg}$ of Ondansetron and transferred into a $100 \mathrm{ml}$ clean dry volumetric flask containing $70 \mathrm{ml}$ of distilled water. The solution was sonicated for $5 \mathrm{~min}$ and the drug was dissolved completely. The volume was made up to the mark with a further quantity of the water to get a stock concentration of Ranitidine and Ondansetron.

Determination of analytical wavelength: Standard dilution containing $10 \mu \mathrm{g} / \mathrm{ml}$ of each RNH and ODH was prepared separately from stock solution and spectra were recorded in the wavelength region of $200-400 \mathrm{~nm}$. The $\lambda$ max was found to be $227.8 \mathrm{~nm}$ for RNH and $248.7 \mathrm{~nm}$ for ODH.

\section{Validation}

\section{Linearity}

Linear response was observed in the concentration range of $2-10 \mu \mathrm{g} / \mathrm{ml}$ for both RNH and ONH. The standard solutions in the range of $2-10 \mu \mathrm{g} / \mathrm{ml}$ were prepared and the absorbances were measured at $227.8 \mathrm{~nm}$ for Ranitidine and $248.7 \mathrm{~nm}$ for Ondansetron. A calibration curve by taking concentration on $\mathrm{X}$-axis and absorbance on Y-axis were plotted. The results were represented in Table 1. 
Open Access Journal of Pharmaceutical Research

\begin{tabular}{|c|c|c|c|}
\hline S. No. & Concentration $(\boldsymbol{\mu g} / \mathbf{m l})$ & Absorbance $(\mathbf{R N H})$ & Absorbance (ODH) \\
\hline 1 & 2 & 0.146 & 0.231 \\
\hline 2 & 4 & 0.223 & 0.389 \\
\hline 3 & 6 & 0.287 & 0.48 \\
\hline 4 & 8 & 0.344 & 0.66 \\
\hline 5 & 10 & 0.412 & 0.808 \\
\hline \multicolumn{2}{|c|}{} & 0.0327 & 0.0713 \\
\hline \multicolumn{2}{|c|}{ Regression Equation (y) } & 0.0865 & 0.0983 \\
\hline \multicolumn{2}{|c|}{ Correlation Coefficient } & $0.0327 \mathrm{x}+0.0865$ & $0.0713 \mathrm{x}+0.0983$ \\
\hline
\end{tabular}

Table 1: Linearity results for RNH and ODH.

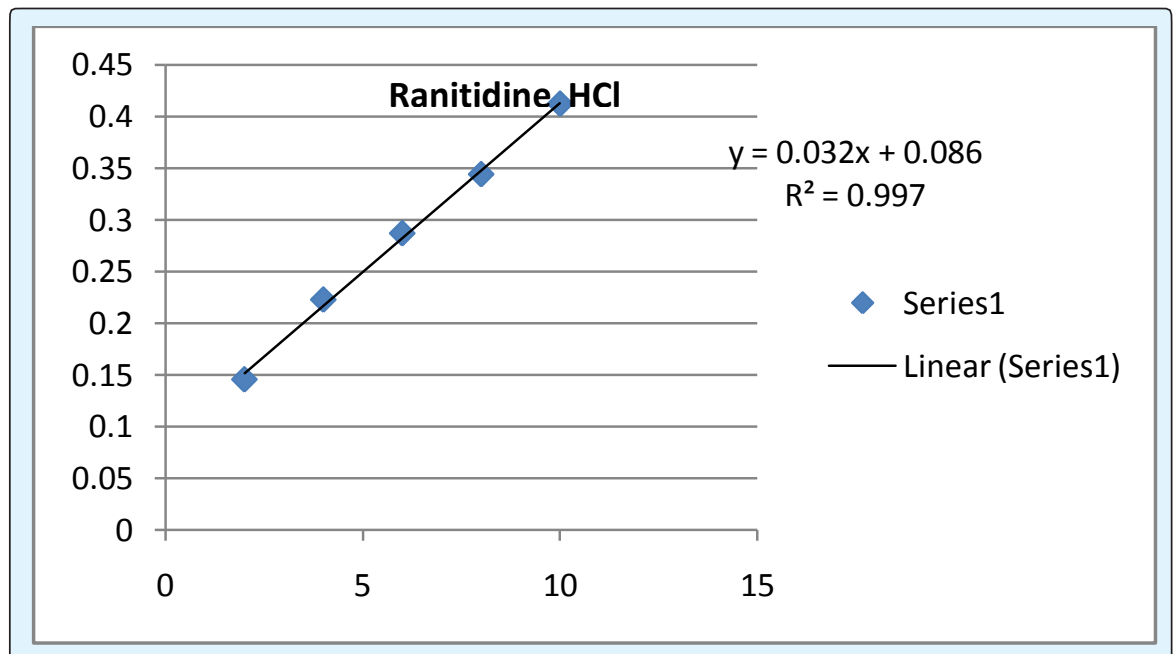

Figure 3: Calibration curve of Ranitidine

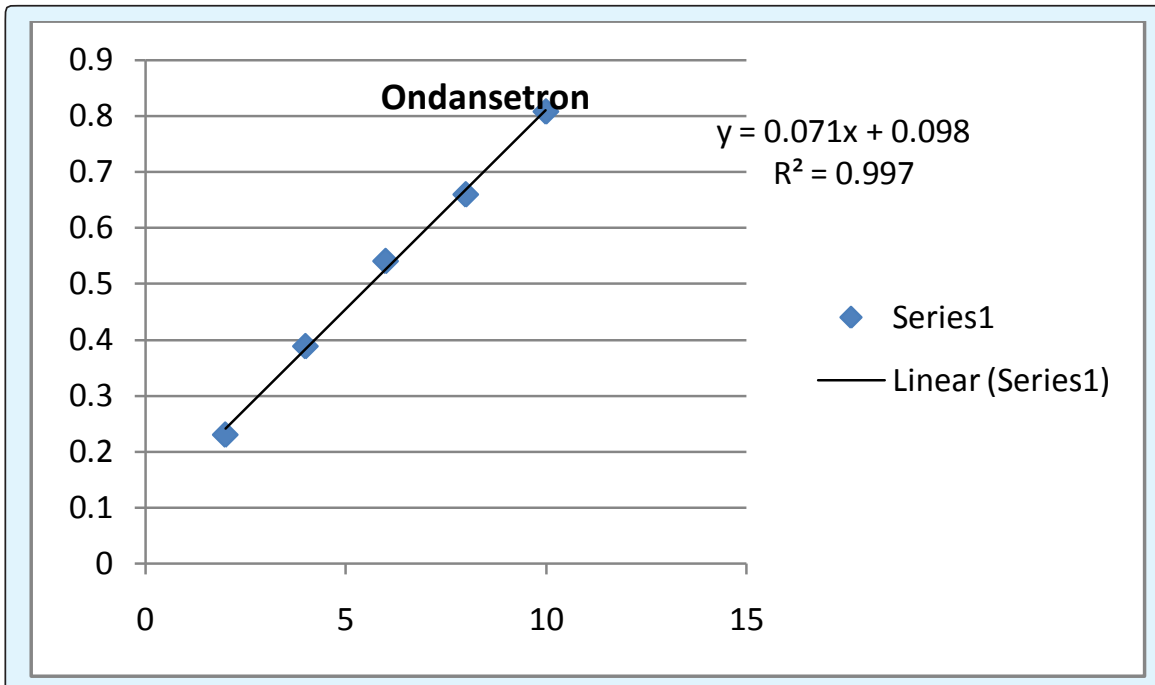

Figure 4: Calibration curve of Ondansetron 


\section{Precision}

Precision was determined by measuring the absorbance of standard solution of same concentration six times in a day (Intra-day) and six different days (Interday). \%RSD values are calculated and compared with acceptance criteria. The data was presented in Tables 2 and 3 .

\begin{tabular}{|c|c|c|c|}
\hline S. No. & Time (Hours) & Absorbance (RNH) & Absorbance (ODH) \\
\hline 1 & 0 & 0.26 & 0.34 \\
\hline 2 & 1 & 0.265 & 0.333 \\
\hline 3 & 2 & 0.261 & 0.34 \\
\hline 4 & 3 & 0.266 & 0.342 \\
\hline 5 & 4 & 0.248 & 0.335 \\
\hline 6 & 5 & 0.271 & 0.341 \\
\hline & Mean & 0.261 & 0.338 \\
\hline & SD & 0.00583 & 0.00149 \\
\hline
\end{tabular}

Table 2: Intra-day Precision results.

\begin{tabular}{|c|c|c|c|}
\hline S. No. & Time (Days) & Absorbance (RNH) & Absorbance (ODH) \\
\hline 1 & 1 & 0.278 & 0.38 \\
\hline 2 & 2 & 0.268 & 0.382 \\
\hline 3 & 3 & 0.266 & 0.381 \\
\hline 4 & 4 & 0.263 & 0.379 \\
\hline 5 & 5 & 0.262 & 0.375 \\
\hline 6 & 6 & 0.261 & 0.371 \\
\hline \multicolumn{2}{|c|}{ Mean } & 0.266 & 0.378 \\
\hline SD & 0.00256 & 0.00207 \\
\hline \%RSD & 0.96 & 0.54 \\
\hline
\end{tabular}

Table 3: Inter-day Precision results.

\section{Accuracy}

Accuracy was determined by performing recovery studies. Recovery studies were conducted by preparing standard solutions of all the two drugs were added equivalent to 50,100 and $150 \%$ of its drug content. These solutions were prepared in triplicate and \% mean recovery was calculated. The results were tabulated in Table 4.

\begin{tabular}{|c|c|c|c|c|c|c|}
\hline Level & Drugs & $\begin{array}{l}\text { Standard conc. } \\
(\mu \mathrm{g} / \mathrm{ml})\end{array}$ & $\begin{array}{c}\text { Conc. added } \\
(\mu \mathrm{g} / \mathrm{ml})\end{array}$ & $\begin{array}{c}\text { Conc. found } \\
(\mu \mathrm{g} / \mathrm{ml})\end{array}$ & \% Recovery & $\begin{array}{c}\text { \% Mean } \\
\text { Recovery }\end{array}$ \\
\hline $50 \%$ & \multirow{3}{*}{ RNH } & \multirow{3}{*}{10} & 3 & 2.98 & 99.33 & \multirow{3}{*}{99.36} \\
\hline $100 \%$ & & & 6 & 5.94 & 99 & \\
\hline $150 \%$ & & & 9 & 8.98 & 99.77 & \\
\hline $50 \%$ & \multirow{3}{*}{ ODH } & \multirow{3}{*}{10} & 3 & 2.96 & 98.66 & \multirow{3}{*}{99.51} \\
\hline $100 \%$ & & & 6 & 6.02 & 100.33 & \\
\hline $150 \%$ & & & 9 & 8.96 & 99.55 & \\
\hline
\end{tabular}

Table 4: Recovery studies. 


\section{Open Access Journal of Pharmaceutical Research}

\section{Robustness}

The robustness study was performed by slight modification in method parameters of Ranitidine and Ondansetron. Samples of RNH and ODH at $100 \mu \mathrm{g} / \mathrm{ml}$ concentration were analyzed under these changed experimental conditions. It was observed that there were no marked changes in absorbances, which demonstrated that the developed method was robust in nature.

\section{Ruggedness}

Ruggedness of the method was confirmed by the analysis of samples was done by different analysts. Samples of Ranitidine and Ondansetron at $100 \mu \mathrm{g} / \mathrm{ml}$ concentration were analyzed by different analysts. It was observed that there were no marked changes in absorbances, which demonstrated that the developed method was rugged in nature.

\section{Limit of detection and Limit of quantification}

Limit of detection (LOD) and Limit of quantification (LOQ) values were calculated based on standard deviation of response and slope of calibration curve. Standard deviation of response can be obtained from y- intercepts of regression line. The LOD and LOQ of Ranitidine and Ondansetron are given in Table 5.

\begin{tabular}{|c|c|c|}
\hline Parameter & $\begin{array}{c}\text { Measured value } \\
\text { RNH }(\mu \mathrm{g} / \mathbf{m l})\end{array}$ & $\begin{array}{c}\text { Measured value } \\
\text { ODH }(\boldsymbol{\mu g} / \mathbf{m l})\end{array}$ \\
\hline Limit of detection & 0.588 & 0.068 \\
\hline $\begin{array}{c}\text { Limit of } \\
\text { quantification }\end{array}$ & 1.764 & 0.204 \\
\hline
\end{tabular}

Table 5: LOD and LOQ values for RNH and ODH.

\section{Analysis of marketed formulation}

Assay was carried out by taking an accurately weighed portion of tablet powder sample equivalent to $10 \mathrm{mg}$ of Ranitidine and $10 \mathrm{mg}$ of Ondansetron was transferred into a $100 \mathrm{ml}$ clean dry volumetric flask containing distilled water and the solution was sonicated for 5 min.

$0.2 \mathrm{ml}$ of the above stock solution were transferred into a $10 \mathrm{ml}$ volumetric flask and the volume was made up to the mark with the water. The assay results were presented in Table 6.

\begin{tabular}{|c|c|c|c|c|}
\hline \multicolumn{2}{|c|}{ Formulation } & $\begin{array}{c}\text { Label } \\
\text { claim }\end{array}$ & $\begin{array}{c}\text { Amount } \\
\text { found }\end{array}$ & \% Assay \\
\hline \multirow{2}{*}{ DORAN-O } & Ranitidine HCl & $5 \mathrm{mg}$ & $4.98 \mathrm{mg}$ & $99.60 \%$ \\
\cline { 2 - 5 } & $\begin{array}{c}\text { Ondansetron } \\
\text { HCl }\end{array}$ & $5 \mathrm{mg}$ & $5.02 \mathrm{mg}$ & $100.40 \%$ \\
\hline
\end{tabular}

Table 6: Assay of marketed formulation.

\section{Summary and Conclusion}

The present method involves development of a method for simultaneous estimation of Ranitidine Hydrochloride and Ondansetron Hydrochloride by using distilled water as a solvent and the peaks of maximum absorbance was measured at $227.8 \mathrm{~nm}$ for Ranitidine Hydrochloride and $248.7 \mathrm{~nm}$ for Ondansetron Hydrochloride. The results of validation parameters were summarized in Table 7 .

\begin{tabular}{|c|c|c|}
\hline Parameter & RNH & ODH \\
\hline Linearity $(\mu \mathrm{g} / \mathrm{ml})$ & $2-10$ & $2-10$ \\
\hline Intra-day Precision $(\% \mathrm{RSD})$ & 0.58 & 0.44 \\
\hline Inter-day Precision $(\% \mathrm{RSD})$ & 0.96 & 0.54 \\
\hline Accuracy $(\%$ recovery) & 99.36 & 99.51 \\
\hline Limit of detection $(\mu \mathrm{g} / \mathrm{ml})$ & 0.588 & 0.068 \\
\hline Limit of quantification $(\mu \mathrm{g} / \mathrm{ml})$ & 1.764 & 0.204 \\
\hline
\end{tabular}

Table 7: Validation Summary.

Based on above results the developed method was simple, precise, robust and accurate for quantification of Ranitidine Hydrochloride and Ondansetron Hydrochloride in pure and tablet dosage form. \%RSD values for intra-day and inter-day precision were below 1 revealed that the method was precise. Satisfactory recovery results shown that the established method was free from interference of excipients. Low LOD and LOQ values makes the method was suitable for routine quality control analysis. So, the proposed method can be utilized for simultaneous analysis of Ranitidine Hydrochloride and Ondansetron Hydrochloride.

\section{References}

1. Brogden RN, Carmine AA, Heel RC, Speight TM, Avery GS (1982) Ranitidine: a review of its pharmacology and therapeutic use in peptic ulcer disease and other allied diseases. Drugs 24(4): 267-303. 


\section{Open Access Journal of Pharmaceutical Research}

2. Wormsley KG (1993) Safety profile of Ranitidine-a review. Drugs 46(6): 976-985.

3. (2014) Indian Pharmacopoeia, Volume III, The Indian Pharmacopoeia Commission, Ghaziabad, India. $\mathrm{p}$ 2643(RNH) \& 2376(ODH).

4. The Merck Index (2006), $14^{\text {th }}$ edition, Merck Research Laboratories, Merck \& Co., Whitehouse Station, NJ, USA. p. 1396(RNH) \& 1180(ODH).

5. Cooke CE, Mehra IV (1994) Oral Ondansetron for preventing nausea and vomiting. Am J Hosp Pharm 51(6): 762-771.

6. Gan LS, Hsyu PH, Pritchard JF, Thakker D (1993) Mechanism of intestinal absorption of Ranitidine and Ondansetron: transport across Caco-2 cell monolayers. Pharm Res 10(12): 1722-1725.

7. (2009) British Pharmacopoeia, Volume II, British Pharmacopoeia Commission Office, London, UK. p 1765(RAT) \& 1506(OST).

8. U.S. Pharmacopoeia 37 National Formulary 32, Volume III, The Unites States Pharmacopoeial Convention, Rockville, MD, USA. 2014; p. 4537(RNH) \& 4070(ODH).

9. Pillai S, Singhvi I (2007) Spectrophotometric simultaneous estimation of Ranitidine Hydrochloride and Ondansetron Hydrochloride from tablet formulation. Indian J Pharma Sci 69(4): 601-604.

10. Vaibhav RM, Palekar SS, Prakash TS, Tauqueer K, Atul SS, et al. (2015) Development and validation of UV spectrophotometric method for the simultaneous estimation of Ranitidine and Ondansetron in bulk and pharmaceutical formulation. WJPR 4(2): 1093-1101.

11. Patel NM, Fursule RA, Shirkhedkar AA, Talele GS (2006) Simultaneous estimation of Ranitidine Hydrochloride and Ondansetron Hydrochloride by RP-HPLC. Asian Journal of Chemistry 18(4): 26912694.

12. Meyyanathan SN, Venkatesh DN, Krishnaveni N, Babu B, Jeyaprakash MR, et al. (2012) A RP-HPLC method for simultaneous estimation of Ondansetron and Ranitidine in pharmaceutical formulation. IJHAS 1(2): 129-132.

13. Priyanka K, Vennela K, Reddy MM (2014) A new RPHPLC method development and validation for simultaneous estimation of Ranitidine and Ondansetron in pharmaceutical dosage form. IJIPSR 2(12): 2971-2979.

14. Vaibhav RM, Palekar SS, Patel MV, Borkar NA, Tekade AR, et al. (2015) Development and validation of RPHPLC method for simultaneous estimation of Ranitidine and Ondansetron in pharmaceutical formulations. WJPR 4(1): 1872-1881.

15. Abdel Hamid ME, Sharma D (2004) Simultaneous quantification of Doxorubicin, Lorazepam, Metoclopramide, Ondansetron and Ranitidine in mixtures by Liquid Chromatography-Tandem Mass Spectrometry. Journal of Liquid Chromatography \& Related Technologies 27(4): 641-660. 